DIGITAL COMMONS
@ UNIVERSITY OF SOUTH FLORIDA

Journal of African Conflicts and

Peace Studies

January 2021

\title{
State Building in Post Conflict Rwanda: Popular Participation of Citizen in Local Conflict Mitigation
}

Innocent Ndahiriwe

University of Rwanda, innocent.ndahiriwe@gmail.com

Follow this and additional works at: https://digitalcommons.usf.edu/jacaps

Part of the African History Commons, African Studies Commons, Emergency and Disaster

Management Commons, Other Political Science Commons, Peace and Conflict Studies Commons, Social

History Commons, and the Social Policy Commons

\section{Recommended Citation}

Ndahiriwe, Innocent (2021) "State Building in Post Conflict Rwanda: Popular Participation of Citizen in Local Conflict Mitigation," Journal of African Conflicts and Peace Studies: Vol. 4: Iss. 2, .

DOI: https://doi.org/10.5038/2325-484X.4.2.1090

Available at: https://digitalcommons.usf.edu/jacaps/vol4/iss2/1

This Article is brought to you for free and open access by the Open Access Journals at Digital Commons @ University of South Florida. It has been accepted for inclusion in Journal of African Conflicts and Peace Studies by an authorized editor of Digital Commons @ University of South Florida. For more information, please contact digitalcommons@usf.edu. 


\section{State Building in Post Conflict Rwanda: Popular Participation of Citizen in Local Conflict Mitigation}

\section{Cover Page Footnote}

Dr Ndahiriwe Innocent is a lecturer in the Department of Development Studies, School of Social, Political and Administrative Sciences and an Associate researcher with the centre for Conflict Management, College of Arts and Social Sciences, University of Rwanda, University Avenue P.O.Box 117 Butare, Huye Innocent.ndahiriwe@gmail.com; indahiriwe@ur.ac.rw Tel+250788878218 


\section{Introduction}

This paper is concerned with the local-level state-building process in Post-conflict Rwanda, specifically focusing on mediation committees as local-level state institutions, where citizens are involved in the mitigation of local-level conflicts. These institutions are involved in building the state at local-level. Rwanda is a country that has historically been identified with perpetual conflicts and "highly centralized governance systems and practices" (Kauzya, 2007:75). Yet State-building is premised on the understanding that to achieve security and development in societies emerging from conflict depends on the existence and the establishment of legitimate state institutions (Paris and Sisk, 2009:3). This is based on the logic that in most cases weak states become a source of insecurity, can harbor terrorists, cause problems to neighbors, and above all they are often prone to internal conflicts (Fukuyama, 2004: xvii), as the case in Rwanda testifies. This justifies the need for "constructing, or reconstructing institutions of governance capable of providing citizens with physical and economic security" (Chandler and Chesterman, 2007:1)

In relation to Rwanda, it is important to point out that during the pre-colonial period "Kings or traditional leaders in Rwanda represented basically all authority" (Kauzya, 2007:75). While during the "colonial and immediate post-colonial periods, governance was characterized by a highly centralized structure" (Kauzya, 2007:75). In all these cases, the citizens at large were excluded from participating in the affairs of their government, either through exclusionary politics or through violent conflicts. This situation of exclusion widened the gap between the state and the citizens, provoking further conflicts, and citizens running out of the country as refugees. Eventually, this contributed to the perpetual conflicts that characterized the Rwandan state, which is in congruent with the argument that

Societies which have experienced one civil war are significantly more likely to experience a second or third war than societies with no prior history of violence; in addition basic living conditions and the average person's access to participation have a significant effect on the likelihood of renewed war, regardless of what has already happened in a previous conflict (Walter, 2004:371).

The point of perpetual conflicts is supported by Tilburg, that the history of Rwanda is a history of conflict and extreme violence (Tilburg, 2008:223), which is rooted in the fact that Rwanda has experienced civil war-like situation in 1959, 1963, 1964, and 1973, 1990-1994 and 1997-2000. As a way of correcting this historical trend, the Rwanda government decided

to establish local-level state institutions, as one of the ways of constructing the state at locallevel. According to the Rwanda government, some of these institutions would act as a forum where citizens resolve issues among their communities with the support of locally elected leaders (Karugarama, 2010:3). ${ }^{2}$ Accordingly, the motivation behind this paper can be found in the fact that, Rwanda has experienced incomplete state building, mainly characterized by unstable state-society relations. This is manifested through the lack of participatory and inclusive functional local state institutions that would bring the state closer to the citizens. This is supported by the fact that these institutions should act as a platform, where the state and the citizens interact at close range and in the process initiate a local state-building process

The second motivation is the establishment of the mediation committees. According to the government of Rwanda, these committees are supposed to solve some of the everyday needs of the citizens through the mitigation of local-level conflicts. This is because the citizens acquire skills to mediate disputes within their communities. In the process this is supposed to reduce the backlog of cases in the normal courts (cf.Karugarama, 2010:1). The government of Rwanda assumes that these committees as local-level state institutions have access to local knowledge, and they understand the nature of local conflicts. Furthermore, these committees can easily relate to the lower levels of society, thus further engage the citizens in the state-building process.

However, the question is whether these committees can deliver post-conflict stabilisation for Rwanda, and the legitimacy of the state through local conflict mitigation. Roberts argues that such institutions create "the means by which reciprocating respect between state and society can create a stable political platform for peaceful development, 
from within, as opposed to perpetuating the assumption that liberal peace building will automatically generate the required consent" (Roberts, 2013:2). But the government of Rwanda believes that these committees are involved in the mitigation of local-level conflicts, and therefore they will contribute to local-level stability. This is based on the theorisation that if these committees mitigate conflicts at local-level, this will lead to the reduction in the frequency and intensity of conflict (cf.Brinkerhoff, 2011:132); in the end citizens would have time to sufficiently contribute to local-level stability and the state-building process in general. This point resonates with Hyden's argument that in most countries, the failure to engage citizens has affected the way policies are implemented. In essence, "the state does not really enter into the solution of this (...) existential problems" (Hyden, 1980:9-18 cited in Herbst, 2000:18). Instead, "the citizens (...) still remain uncaptured" (Hyden, 1980:5), thus the citizens are not effectively participating in the local state-building process. In a similar argument, Herbst contends that the viability of any state depends on the loyalty of its citizens (Herbst, 2000:3). The loyalty that Herbst is talking about depends on what the citizens get from the state, since the citizens offer legitimacy and the state provides protection. The loyalty of the citizens is also characterised by the participation of citizens in the local state building process.

Furthermore, it is, worthwhile pointing out that these committees are involved in the mitigation of "the micro-foundations of conflict" (Verwimp and Justino, 2009:307). They cater for individual and group heterogeneity, supporting the logic that, "conflicts shape the lives of and are shaped by the behavior of individuals, households, communities and governments. But, the degree of involvement in the conflict of each of these agents varies considerably from conflict to conflict" (Verwimp and Justino, 2009:308). This implies that a strategy that caters for the heterogeneous nature of conflicts may be necessary, and this is what these committees are supposed to carry out. The disputes that are handled by these committees are social and economic, but in the end they can equally become political.

Hence the aim of the paper is to provide a better understanding of the dynamics of citizen participation in local conflict mitigation as a strategy for local state building. This leads us to the question how does state lead local conflict mitigation in post-conflict Rwanda work? And how is it experienced by citizens in terms of participation, accountability and legitimacy? As outlined above, this aim is motivated by the desire to see Rwanda have less violent conflicts, bearing in mind that Rwanda has been in and out of severe conflicts for the last forty years. The study specifically focuses on the mediation committees as local-level state institutions where citizens are participating in local conflict mitigation as a strategy for local-level state-building (see the definition of conflict mitigation, Brinkerhoff, 2011:132). ${ }^{3}$

However, this paper acknowledges that there is need to "strengthen local-level state institutions in order for them to play a more representative, responsive and constructive role in the everyday lives of the local citizens" (Ribot, 2002:3). In addition, it is based on the fact that "the strength of the state rests in its responsiveness to citizens and their needs by enhancing citizens' ability to act on their own behalf and on behalf of others" (Commission on Human Security, 2003:11).

\footnotetext{
${ }^{2}$ Karugarama was the Minister of Justice in Rwanda up to 2012.

${ }^{3}$ Also see the definitions and assessment literature provided by the USAID Conflict Assessment Framework, 2012:4 and the USAID, Democratic Decentralisation Programming Handbook, 2009:21.
} 
I investigate local state building from the perspective of state-society relations, in other words how the citizens relate to the local state institution. My investigation is based on the definition provided by Paris and Sisk that state-building "is the construction of legitimate governmental institutions in countries that are emerging from conflicts" (Paris and Sisk, 2009:14), bearing in mind that the legitimacy of the state emanates from its citizens. I regard state-society relations as "the interaction and the interdependency between the state and its citizens" (Sellers, 2010:2). Ultimately, positive state-society relations enhance the legitimacy of the state, which is generated through the interaction between the state and the citizens. This is based on the logic that a citizen is "someone with rights, aspirations and responsibilities to others in the community and to the state, which also implies a relationship to the state and all those living within its borders" (Benequista, 2010:4). The focus is on "the relations and relational functions of the state and society institutions, and how the state derives its legitimacy through its interaction with the citizens" (Haider, 2010:6), and this is reflected in the engagement between the citizens and the mediation committees as a microcosm of the state at local-level. The discussion in this paper will be guided by the following sub-questions.

- How are the citizens participating in the local conflict mitigation process?

- What are the accountability relations between the citizens and other state actors at local-level involved in the conflict mitigation process?

- What are the experiences of the citizens and other local actors in relation to local-state legitimacy through local conflict mitigation?

In this paper, I define citizen participation as citizens' "active engagement with the state institutions" (Manor, 1998:7), and in terms of how "citizens' exercise influence and control over decisions that affect them" (Devas and Grant, 2003:9).

Ultimately, this calls for a strategy of building the state at the local-level as it hypothetically contributes to local state-society relations, and the efficiency of the state at local-level with popular participation of citizens at local-level. In terms of local state legitimacy, understanding peoples' views and experiences may not be an easy task but this paper acknowledges that "no one voice is more important than another (...), to understand the processes one has to give voice to all of those interconnected experiences" (Nordstrom, 1997:8). This means the views and experiences of all the citizens and other local actors will be interpreted in an interconnected manner.

In terms of methodology, this is an explorative and an empirical study, acknowledging that different stories can be told from a similar set of data, aiming at getting information and experiences for interpretation. The study is based on original empirical data collected in the three districts of Karongi, Musanze and Huye districts which have particularly been affected by conflict for some time. The North and North-Western part of Rwanda, where the two districts, namely Musanze and Karongi are located, are specifically a conflict prone area. The situation is worsened by the fact that they are situated near the volatile Eastern part of D.R.Congo. Through physically attending the mediation committee (MCs) meetings and interviewing the MC members, local state agents and the litigants, I drew general conclusions from the interviews after the mediation sessions. I physically attended the mediation meetings, looked at the process, wrote down the details of the meetings and followed the progress of the meetings.

The selection was convenient random sampling, which was depending on the availability of the litigants and other actors. Snow ball sampling was carried out as a way of identifying people who had appeared before the MCs. There was also document review, specifically I analysed the registers of disputes. This was done with the objective of knowing the type and the number of disputes that appeared before the MCs. This helped me understand the most common disputes in each of the study areas. 


\section{Mediation committees as local-level state institutions}

In this section I present the mediation committees in Rwanda. I present their mandate in terms of the existing legal documents namely the Constitution of the Republic of Rwanda of 2003, Organic law No. 02/2010/OL of 09/06/2010, Presidential order No.57/01/15/10/2006, and Ministerial Order No.82/08.11 of 02/05/2011. These are the laws that govern the operations of these committees. According to available policy documents the main objective of the decentralisation policy in Rwanda is to ensure political, economic, managerial, administrative, and technical empowerment of the local populations (MINALOC, 2008:4), and the policy gets its authority from Article 167 of the Rwandan constitution. Accordingly Article 167 stipulates that with the promulgation of the constitution in 2003, Public Administration in Rwanda became a decentralised function and districts became decentralised entities with a legal status, falling under the Ministry having local government in its functions (The constitution of the Republic of Rwanda, 2003; Article, 167). Therefore these committees are local-level state institutions operating within the framework of the decentralisation policy. They fall under the sector and the district respectively, while their specific mandate emanates from the constitution of the Republic of Rwanda, Article 159.

The constitution of Rwanda mentions that these "mediation committees are responsible for the mediation of parties to certain disputes, involving matters determined by law before filing a case with the court of first instance" (Constitution of the Republic of Rwanda 2003, Article 159; Organic law No.02/2010/OL of 09/06/2010). In addition, these committees provide a framework for "mandatory mediation before filing a case in the court of first instance" (Article, 3 Organic law No.02/2010 of 09/06/2010). But above all, these committees as local-level state institutions provide a platform where the citizens interact with the state at close range. This is important because through these committees the citizens are supposed to share knowledge and information as a shared resource (Hess and Ostrom, 2007:4). Above all, these committees carry out public functions, and the committee members are therefore state agents.

These committees are local state institutions and Organic law No.02/2010/of 09/06/2010 stipulates that these committees have jurisdiction over civil and criminal cases, as long as the value of these cases do not go above three million Rwandan Francs. Their mandate emanates from Article, 8 of the same Organic law and it states that the mediation committees at the cell level have the competence to examine the following civil cases

a) Land and other immovable assets whose value does not exceed 3 million Rwandan Francs $b$ ) cattle and other movable assets whose value does not exceed 1 million Rwandan francs $c$ ) breach of contractual obligations in case the subject matter does not exceed the value of One million Rwandan francs d) breach of employment obligations between individuals with a value of less than one hundred thousand Rwandan francs (100, 000Rwf) e) family cases other than those related to civil status (Article 8, Organic law No. 02/2010/OL of 09/06/2010)

The above are related to civil cases; in relation to criminal cases Article 9 of the same Organic law mentions that the MCs have the competence to examine criminal disputes related to

a) Removing or displacing land and plot boundaries b) Any kind of destruction or damage to crops in any manner if value of crops destroyed or damaged do not exceed three million Rwanda Francs c) insults d) defamation e) stealing crops or standing crops $f$ ) larceny $g$ ) concealment of goods stolen during larceny $h$ ) breach of trust $i$ )

Killing or wounding without intent domestic or wild animals belonging to another person j) destroying or damaging without intent, assets belonging to another person $k$ ) Any type of assault to a person without causing physical harm (Article 9, Organic law No.02//2010/OL of 09/06/2010). 
All the above illustrate the legal mandate that these committees have, and the mediation process is mandatory before filing a case in the court of first instance (cf. the Constitution of the Republic of Rwanda, 2003; Article 159). All the disputes mentioned above whether civil or criminal pass through the mediation committees as long as their value is below three million Rwandan francs. 4

In the next section I present studies that have been made on local-level state institutions involved in local conflict mitigation and operating within the local government structure,

\section{Comparison of the Mediation committees in Rwanda with other committees involved in local conflict mitigation}

This study is unique in that it attempts to do what "few studies have done to empirically understand the legitimacy generated by local-level state institutions and specifically from the perspective of the citizens upon whose consent to rule legitimacy depends" (Robins, 2013:45). I am basing myself from the argument of Robins who argues that traditionally; state building has been a top-down affaire, built on "international standard procedures, material resources and capacity" (Richmond, 2013:390). While acknowledging the importance of the top down approach, this paper puts emphasis on building the state at local- level because it makes use of the "local knowledge, capacities, and builds relationships and partnerships that form peace and the state" (Richmond, 2013:393). Though, Autesserre argues that "the idea of becoming involved at the local-level clashed so fundamentally with existing cultural norms," especially when there are some other interests involved at the local level (Autesserre, 2010:11).

In such a process, the citizens deal with "the root causes of conflicts that impact on their lives" (Richmond, 2013:395), and eventually contribute to the legitimacy of the state (Papagianni, 2008:50). However, this would need to "build relationships with citizens, subjects, the oppressed and marginalised on their own terms" (Richmond, 2013:395). This would be done through their contribution to "the everyday needs as a source of legitimacy for the state" (Roberts, 2013:6). It is even more aptly put by Milliken and Krause who argue that, everyday legitimacy emanates from the provision of everyday needs of the citizens, as a major source of legitimacy. Milliken and Krause argue that there is need for "a stable politicolegal framework to foster economic growth and development, and the rise of the welfare and entitlement state as a powerful glue that binds citizens to their state" (Milliken and Krause, 2002:760). The above metaphor by Milliken and Krause shows that the legitimacy of the state depends on what the citizens get from the state, and the image of the glue is meant to serve that purpose.

There are a number of studies on state-building and local-level stability, however, I will particularly discuss a few studies in detail and I will begin with the study by Alexander Seth Curley. Through an ethnographic study Seth Alexander Curley in 2011, examines the Ugandan local government system as it relates to the everyday life in rural Uganda. Curley studied the elected local councils in Uganda, which play "an intimate role in the everyday lives of the citizens; they adjudicate local disputes as courts, manage economic development projects of various scales, provide state security and finally provide the basis of citizen participation in civic life" (Curley, 2011: i). The main question of this study sought to seek answers on how citizens participated in the local councils in Uganda. Eventually, the findings of this study were that, "these councils had managed to create authority into village life, and citizens had gained techniques of social integration, and they were using them effectively to solve problems of daily life" (Curley, 2011: i). However, other findings indicated that, firstly the civil servants undermined these institutions through their actions, their sense of entitlements, and their desire for control of these institutions. Secondly, though the councils were local entities, still the bureaucracy had left the operations of these councils to the communities.

\footnotetext{
${ }^{4}$ This is the equivalent of 4500 US dollars.
} 
In other words, these councils were not getting any support from the bureaucracy and this undermined their performance. Thirdly, the leaders of these councils continued to construct their authority by asserting their connections to the patrimonial state, which at times undermined their autonomy. Fourthly, it was found that the citizens still felt they were part of the state and needed state authority (Curley, 2011). This meant that the councils had not been fully integrated into the local governance structures. ${ }^{5}$

It is important to mention that like the mediation committees in Rwanda; these committees functioned on voluntary basis; they were elected and relied primarily on voluntary contributions from the community in order for them to accomplish their tasks (Lambright, 2011:24). According to Lubanga, "the statute formally transformed the councils as Uganda's new local government institutions and sought to empower local communities, secure local participation in decision making and development and improve service delivery" (Lubanga, 1996:51). But despite acknowledging the importance of these committees, "the statute failed to empower these committees, and instead reinforced the power of central field administrators" (Lambright, 2011:25). In the end the committees did not serve the objective that they were supposed to achieve. Unlike the MCs, these committees lacked sufficient legal authority, while the authority of the MCs emanates from the constitution of the Republic of Rwanda (Article 159) and there are laws that clearly stipulate their roles and functions (Organic law No.02/210/09/06/2010). Therefore these committees differ quite broadly in terms of legal authority.

There are other scholarly studies on local committees, which carry out decentralized functions and these are studies by Poteete and Ribot (2011). Poteete and Ribot argue that "Decentralization promises to empower local actors, but threatens others with a loss of power" (Poteete and Ribot, 2011), and they refer to this as "repertoires of domination" which means a set of acts that actors perform to defend or entrench and expand their positions of dominance in relation to other actors within the process of decentralization (Poteete and Ribot, 2011). Some of these actors are the rich and the wealthy citizens, and the elite members of society. This is reflected in two case studies on Botswana's Community Based Natural Resource Management program for wildlife and the decentralization of forestry management in Senegal. The similarity between these studies and the MCs, which is the focus of this paper, is that both are carrying out decentralized functions. They are carrying out public functions, which were initially the responsibility of the state and they are community based, and both reflect a situation where some actors have lost power, authority, and resources.

In all the above cases as it is in the MCs, the citizens are involved in the local-level decision making process. Specifically, in the case of the MCs in Rwanda, the reduction in disputes and conflicts at local-level means that there will be a reduction of disputes going to the courts of law, and this means loss of revenue to the lawyers who are normally engaged with the courts of law. It is important to mention that the conflict mediation process in Rwanda was initially the responsibility of the family, the clan and other traditional leaders, most likely some of these actors at local-level who have been involved in the mitigation of conflicts at local-level may not be happy with the establishment of the MCs.

Particularly in the case of Botswana, the revenue from tourism was going to the central government, this meant that the state bureaucrats who were managing the revenue that was coming from tourism may not be happy with the involvement of citizens in the management of the local-level wild life activities under the Botswana Community Based Natural Resource Management (CBNRM) program, and they will fight at all costs to undermine the involvement of citizens in the management of the natural resources at local- community level. Above all there were no accountability relations between the state bureaucrats and the citizens, as the state bureaucrats were doing whatever they wanted with the resources at local level. The same thing applies to forestry management in Senegal. ${ }^{6}$

\footnotetext{
${ }^{5}$ Also see other studies on the local councils in Uganda, by Lubanga F.X.K, 1996, and Nsibambi Apollo, 1991

${ }^{6}$ Also see separate studies by Poteete and Ribot, on Botswana and Senegal respectively.
} 
The difference is that whereas the MCs are dealing with the mitigation of disputes at the level of the individual, the family, and among families at local-community level, the other two cases mentioned above are dealing with the management of natural resources at local community level.

Still comparing the MCs with other committees else where in the world, a UNDP study in Bangladesh indicated that, the village courts in Bangladesh had been able to restore broken social ties, which in most cases became a problem to village life not only in Bangladesh but also in other developing countries including Rwanda. According to this UNDP study, these committees had ultimately created a sense of safety and security within the village communities. The report indicates that "more than two thirds of beneficiaries reported that social problems and petty crimes occur less frequently" after the establishment of the village courts. In addition, through empowering the citizens to resolve disputes at the local-level in an affordable, transparent manner, the village courts had increased access to justice for the disadvantaged and marginalised members of society, and they had equally reduced the huge backlog of cases in the higher courts. Eventually, the village courts had reduced travel costs to the courts of law and the courts were now able to carry out investigations, reach decisions easily and implement a verdict with ease and efficiency that the higher courts had failed to achieve. ${ }^{7}$

Yet another study still on the village courts in Bangladesh, entitled "Dispensing Justice Locally: A study of Two Village courts in Bangladesh" (Balayet Hossain, 2012). The findings of this study indicated that

a) there were lack of legal awareness of the service seekers and providers. The citizens did not understand the relevance of the village courts $b$ ) there was complexity and lack of clarity of the act, rules and procedures were difficult to understand for both the service providers and those seeking justice c) there was lack of competence on the part of the village court members $d$ ) there was lack of sufficient resources from the local government e) lack of monitoring and supervision of the court activities $f$ ) absence of legal aid and support mechanisms of the NGOs (Balayet Hossain, 2012:50-52).

As mentioned above, comparing the above findings to the findings in this paper, one realises that there are some differences and some similarities. In Rwanda all the laws are written in the local language, and the citizens speak and write in Kinyarwanda. The laws that the MCs use are in the local language, and the Ministry of Justice tried to simplify the language, such that the citizens did not have any problem with the understanding of the various laws. ${ }^{8}$ Further comparisons could be made in the next sections discussing the empirical data of this paper.

However, it is important to mention, as argued by Menkhaus that there is a "vast literature often little noticed, and scattered across several disciplines, covering most,.(..), of the world's post conflict states.(.....) where most stability and many of the qualities associated with peace have been provided by local mobilisation" (Menkhaus, 2006, cited in Richmond, 2013:380). As observed from the studies mentioned above there is need for the citizens to get "involved in everyday matters of peace and its infrastructure, in security, political, economic and social realms, drawing on socio-historical processes. (....). Reshaping governance and the modern state" (Richmond, 2013:380). Hence in this paper, through studying these committees, I present the experience of Rwanda as a Post-conflict country in relation to local conflict mitigation as one of the ways to construct the state at local-level. This is because stability is important for any sustainable state-building process.

\footnotetext{
${ }^{7}$ http://www.undp.org/content/undp/en/home/ourwork/democraticgovernance/successstories/through-villagecourts--justice-for-all-in-bangladesh/down loaded on 16th March, 2014.

${ }^{8}$ There are booklets in the local language that were written by the Ministry of Justice. Their titles are "Inyigisho

Zigenewe Abunzi" meaning Training Manual for Mediators.
} 


\section{How does state-led conflict mitigation work?}

In terms of accountability, where accountability means answerability, the MCs are supposed to be accountable to both the citizens and the nation. Accountability to the citizens could be seen from the fact that the mediation sessions are held in public. The intention

would be to show a transparent process, but this could also have its own problems, since some people could fear to wash their dirty linen in public, and some disadvantaged groups or other categories of citizens could be marginalised. Alternatively, accountability could be seen from the perspective of elections. The MCs are elected by the citizens and specifically by the cell and sector councils. The cell council elects the cell MC, while the sector council elects the sector MC. According to Presidential order No.57/01/2006, Article 27, "the cell council comprises of all residents of the cell who have at least eighteen (18) years of age." This means that all residents in a cell make the cell council, and they are the ones responsible for electing the cell MC. While the sector council is comprised of citizens representing various interest groups namely Youth, Women, cell co-ordinators, Teachers, Co-operatives, NGOs and representatives of the health centres in the sector (Article, 59 Presidential Order No. 57/01 of 15/10/2006). Regular Elections would work as another accountability mechanism, as these committees would be accountable to the citizens since the citizens elect them, and they have the prerogative of not electing them in the next elections. But those in power, for their own benefit, manipulate most elections. ${ }^{9}$ Relating to the MCs, the elections of the MC members take place after every five years (Article, 4 of Organic law No. 02/2010/OL of 09/06/2010). These elections are organised by the National Electoral Commission, which is mandated to organise all National Elections including Presidential elections (cf. Article 6 of Organic law, No.02/2010OL of 09/06/2010). The accountability mechanisms mentioned above shows the authority of the MCs as state institutions. In terms of the accountability to the state, the MCs make an oath and the oath requests for their loyalty to the nation (cf. the constitution of the Republic of 2003; Article, 61), this also makes them state institutions.

In relation to the checks and balances in the management of the MCs, Article 33, of the ministerial order No. 82/08.11 of 02/05/2011, states that any mediator shall be required to honour the oath taken after the elections. While Article 34 of the above-mentioned ministerial order, states that the MCs have obligations and some of these obligations are that the members of the MCs should be honest, and exemplary in their day-to-day activities. These obligations are supposed to check their behaviour as state institutions, and can be used to sanction any member of the MCs who does not carry out his/her activities as expected ${ }^{10}$.

As far as the suspension of a member of the mediation committee is concerned, Organic law No.2/2010 of 09/06/2010, Article 30, stipulates that "the mediation committee may at its own initiative or upon a request by the population, suspend one of its members for a period of one month on the ground of partiality, or any other misconduct." In case of dismissal the same Article 30 of the above law mentions that, "a mediation committee member may be dismissed from his/her duties by the electoral college, if it is evident that he/she is no longer able to fulfil his/her duties." The Electoral College being mentioned above is the cell council, in case of the cell MC, or the sector council in case of the sector MC. But in all these cases, the suspension of any member of the mediation committee should be approved by the executive secretariat in charge of coordinating the activities of the mediation committees (Ministerial order No. 82/08.11 of 02/05/2011).

In relation to the MCs as state agents that provide voluntary service, this is stipulated in Organic law No.02/2010/OL of 09/06/2010; Article 3, which mentions that the MCs are supposed to provide voluntary work. In the next section I present the experiences of the citizens in relation to participation, accountability relations and local state legitimacy.

\footnotetext{
${ }^{9}$ Golooba Mutebi calls it the episodic nature of Voting (See Golooba, 2004:304).

${ }^{10}$ See Organic law No.02/2010 of 09/06/2010; Article 29 and 30 of the Organic law, on the Mediation committee code of conduct.
} 


\section{Experiences of the citizens in relation to participation, accountability relations and local state legitimacy}

In this section I discuss the experiences of the citizens and other local actors in relation to participation, accountability and local-state legitimacy through local conflict mitigation? In relation to citizen participation, I illustrate how citizens experienced the conflict mitigation process through their participation in the mediation committees. Citizen participation is defined in terms of citizens' active engagement with public institutions (cf. Manor, 1998) or citizen engagement with the state (Devas and Grant, 2003), and how the citizens exercise influence and control over decisions that affect them (Devas and Grant, 2003).

Citizen participation is particularly shown through how the Citizens interact with the MCs as state agents, Citizens act as litigants, as the general public assisting the MCs to make decisions that are supposed to be implemented by other local state agents. Firstly, citizen participation in the MCs resulted in building relationships at family level. In addition it was discovered that the disputes taken to the MCs were as a consequence of past political violence, and the MCs acted as a forum for solving everyday disputes. Secondly, citizen participation through oral testimonies led to solving disputes over inherited property. Though they would also at times intensify disputes, especially domestic conflicts between husbands and wives; for example men would continue tormenting their wives especially when the MCs made decisions favouring the wives. Furthermore, through their participation, the MCs were able to handle disputes from the disadvantaged members of the community, who were not able to go through normal courts due to high costs of litigation.

The above aside, it is important to observe that another level of participation could also be seen from the fact that whenever decisions were made by the MCs, the executive secretaries as local state agents acting on behalf of the state, would implement the decisions of the MCs. This showed the instrumental and corroborative arrangement between the local state agents, the MCs and the citizens (cf. Golooba, 2005), and this is participation at the level of local state agents.

Generally, in relation to the disputes that appeared in all the study areas combined, the data reveals the heterogeneous nature of disputes and conflicts in Rwanda. Hence it is important that we acknowledge the role of heterogeneity of conflicts, and that focusing on one type of dispute as the main source of conflicts in post conflict countries like Rwanda may not provide us with the best insight. It is better to focus on heterogeneity as a big factor in the understanding of conflicts.

Accordingly, Devas and Grant argue that, "Participation can be inhibited by social dynamics of exclusion and inclusion" (Devas and Grant, 2003:309). Inclusiveness is important because in the process of conflict mitigation, the mediators depend on the views and information provided by the citizens. It is therefore important to involve more citizens in order to get more information since the decision to be made in most cases depends on the local history, which can only be provided by all the categories of citizens. Doughty points out that "society rebuilding is not uniform (...) it depends on people's localised decisions and actions" (e.g. Doughty, 2011:338). In that regard inclusiveness is an important factor in the conflict mitigation process, as the citizens are supposed to provide local knowledge and history. 
Using inclusiveness as an aspect of participation, this study discovered that the wives of men working under the $\mathrm{TIG}^{11}$ programme, did not attend the MCs, and especially did not attend disputes related to land. The argument they presented was that land belongs to the head of the family, who is always a man. This was more pronounced in Rubengera sector, though it may have similarly occurred in other sectors. Despite advances in women's rights to land, this revealed how some women are still marginalized in some parts of the Rwandan society.

More specifically, in the sector of Rubengera the study discovered that the poor and the disadvantaged members of the community were not excluded, but there was a category of citizens that seemed not to make use of these committees and these were the "Batwa." 12 They did not use these committees, as expected and they did not appear before these committees, because they felt their ideas were inferior. Their disputes were solved at family level. ${ }^{13}$ Though this problem was more prominent in Rubengera it does not mean that this problem does not exist in other sectors.

Another important factor in citizen participation is the issue of benefits (cf. Blair, 2000; Kauzya, $\left.2005^{14}\right)$. In terms of citizen participation in the MCs there was evidence that the citizens had acquired legal awareness. Through these committees the citizens shared experiences. Notably, the citizens seem to have internalised some of the laws that concern them. This was particularly clear with the Succession and Inheritance law of 1999 that gave women right to property and to inherit property from their parents, as mentioned above. The attendance and the participation of women in these committees have enabled them to understand the application, and the relevance of this law to the lives of the local women. One other category of citizens that have benefited from these committees, are the genocide survivors. As most of these citizens lost their relatives and property, the Rwandan government regards this category of citizens as disadvantaged members of the local community. The local authorities build houses for them and I discovered that some of those who were born during the genocide period (and did not know the property that the parents left behind) were in most cases helped by the MCs in identifying their property. The MCs were able to identify the property as a result of the assistance from the surviving citizens who were familiar with the property.

Regarding citizen participation in the committees, there were many cases of disputes related to employees who were denied their payments by their employers. This was prominent in Ngoma sector. In such situations, these employees turned to the MCs. It is important to note that participation or taking the disputes to the MCs did not require money and therefore most citizens, especially the poor and disadvantaged were able to take their disputes to the MCs. This resonates with Manor's point that "when reforms inspire disadvantaged groups to engage in public affairs, their confidence, skills, connections, organizational strength and thus their capacity to influence their destinies grow" (Manor, 2004:27). This was observed in all the sectors, particularly with women who had domestic problems and some employees, who were not being paid by their employers.

\footnotetext{
${ }^{11}$ This is in French and it stands for "Travaul d'interest Generaux." These are the citizens who are serving a prison sentence outside the prisons. They were convicted of the Gacaca courts of genocide related offences. They fall under the Rwanda collection centres. They pleaded guilty of the crimes and they are serving their sentence while staying in their homes. They are involved in community work like building schools, roads and health units. They work three days a weekand the other three days they are in their homes.

12 These are one of the indigenous communities in Rwanda

13 The "Batwa" are regarded as the historically disadvantaged citizens in Rwanda. They possibly solve their disputes through the family heads. They do not go public. Many of them are still conservative in their traditions. In the study I did not find cases of this category of citizens bringing their disputes to the MCs, possibly they mitigate their disputes at family level. Possibly a study in this regard should be carried out.

${ }^{14}$ Blair and Kauzya argue that genuine participation goes with consumption or the benefits that those participating will get through their participation
} 
One of the key findings in relation to benefits is that participation of citizens in the mediation process enables the citizens to acquire the capacity to mitigate conflicts within their localities. The citizens learnt how to mitigate these disputes, and eventually through this process the citizens acquired knowledge and understanding of the nature and context of these disputes. Ultimately they learnt how to mitigate these conflicts within their local communities. This resonates with the argument presented by Khadiagala that in post conflict situations, leadership training needs to be addressed (e.g Khadiagala, 2006:9), especially in relation to the management of conflicts at local-level. Through training, which these committees have had, the aspect of leadership is addressed, and this is also one of the benefits that come with participating in the MCs.

Despite the above benefits, there was another category of citizens who could not take their employers to the MCs after failing to get their actual remuneration since taking them to the MCs meant losing their jobs. The reason that was provided is that some category of citizens did not have the confidence to appear before the MCs (most common in Ngoma sector). These feelings of not having the necessary confidence, was as a result of the fact that some of the citizens were poor and their employers intimidated and harassed them. Ultimately, they accepted the situation the way it was, because if they took their employers to the MCs, they would end up losing their jobs. Yet their families heavily depended on the little income they get from their jobs, which resonates with the argument of Eyben and Ladbury that

Even when the state creates opportunities for dialogue (....), some people, particularly those living in poverty or subject to discrimination and exclusion, are too alienated or oppressed to enter the debate. Or, when they do try, they find themselves silenced through not being able to speak the 'right' language - or they may be ignored or threatened because more powerful groups believe they have no right to a voice (Eyben and Ladbury, 2006)

In relation to participation in the meetings, I found out that the majority of the respondents appreciated the work of the MCs but other citizens complained that the meetings usually began late, and were at times irregular, which was attributed to the MCs lack of motivation. This situation was more prominent in Musanze sector, and Rubengera sectors, where the litigants and the witnesses had to travel far to attend the meetings. This brought the litigants to complain a great deal and the situation affected the attitude and the relationship between the citizens and the MCs. Some of the citizens related this behaviour to the fact that the mediators provided voluntary work and tardiness was thus the effect of low motivation among the mediators. It is important to point out that all actors including the mediators themselves, as well as the state agents at the local level, mentioned the above problem. This is similar to what Golooba found out in his study on the local councils in Uganda that, "attendance at village meetings and levels of participation in self-help projects plummeted (...). As enthusiasm for participation among ordinary people fell, so did it among their leaders. Once held regularly, consultative meetings became less and less frequent" (Golooba, 2004). A similar situation was observed in some MCs as mentioned above.

However, in Rubengera sector, the majority of citizens indicated that being a mediator did not require legal knowledge, as most of the disputes were day to day disputes. This is different from what I got from some sectors for example in Ngoma sector, where some people did not believe in what the MCs were doing especially in relation to their capacity. Instead, some of the elite citizens especially the lawyers regarded the institution of the MCs as an abuse to the justice system in Rwanda.

In general, whether the disputes had reduced in terms of frequency, the majority of the citizens indicated that the number of disputes coming to the MCs had reduced. However, it would be difficult to conclude that the reduction of disputes coming to the MCs meant the reduction of conflicts at local community level. But, one of the key findings related to citizen participation is that the participation of citizens created dialogue, among the citizens themselves, between the MCs and other local state-agents, between the MCs and the citizens, 
between the citizens and other local state actors (for example the executive secretary who received the disputes for processing, always discussed with citizens who brought the disputes and he/she would first counsel them). This was revealed through regular dialogue, which was both formal and informal. This dialogue was important since the citizens learnt how to solve conflicts, which is an important aspect in post-conflict reconstruction. In the next section, we look at accountability relations.

\section{Accountability relations}

To understand the accountability relations between the citizens and other state actors at locallevel involved in the conflict mitigation process, this paper is guided by the conceptualisation of accountability as "the answerability and having the obligation to answer questions regarding decisions or actions taken" (Brinkerhoff, 2001). The purpose of accountability is to control the abuse and misuse of public authority, provide assurance in terms of adherence to the law and public service values and lastly to promote continuous improvement in terms of the management of public affairs (Aucoin and Heitzman, 2000:46). The end result is to improve institutional performance.

In terms of availability of information, the findings indicate that most of the citizens do not know how the appeals should be submitted. This affects the relationship between the citizens and the MCs and falls under downward accountability. Importantly, the law indicates that appeal cases should be submitted to the sector within a period of thirty days of the MCs decision (see Organic law No.02/2010/OL of 09/06/2010). Yet most citizens interviewed in did not know that the appeal cases had to be submitted to the sector council within thirty days. The effect this had on the conflict mitigation process was that after thirty days the citizens could not appeal. In the process many citizens lost the disputes because of not knowing this vital piece of information. ${ }^{15}$ As stated above, this affects the reciprocal relationship between the MC and the citizens, which is crucial for effective accountability (e.g. Kim, 2012). The importance of availability of information is that it enhances transparency and limits conflicts and complaints among the citizens, as the saying goes: knowledge is power. Above all the citizens cannot hold these committees accountable when they are ignorant of the law and how things are supposed to be done (cf. Aucoin and Heinzman, 2000).

In case of horizontal accountability, that is, the accountability between the MCs and other state agents, the citizens seem not to understand the difference between the MCs, and the local government staff. Citizens still think that the local governments influence the decision of the MCs. For example one litigant complained that "there is no clear way of distinguishing the difference among these organs. In most cases you find the local leaders doing almost everything; the executive secretary does everything" (Int. $7 g$ ). Another litigant added that "in most cases you find the local leaders indirectly influencing the decisions of the MCs" (Int.6g)

On the accountability relations between the MCs and other local state agents, the general view is that the MCs are doing a good job, facilitating their work. Therefore, there are state agents at local-level who believe that the MCs are better placed to mitigate local-level conflicts. This is because they are part of the local community. While the other state agents come outside the locality where the MCs are located, as such they do not understand local issues and they lack the necessary local knowledge. For example one state agent mentioned that "Who among us can manage the work that these people are doing? Most of the disputes that are handled by these people are extremely local. We cannot understand them" (Int.34).

\footnotetext{
${ }^{15}$ See Article, 26, Organic law No.02/2010/OL of 09/06/2010
} 
In a discussion with some MC members the study discovered that, at times, some of the staff of the local administration despised them, saying that they were not educated enough to do what they were doing, as mentioned by one member of the MC that "at times some staff of the local administration despise us and they say that some of us are not educated enough to do what we are doing. This becomes a hindrance to our relationship (Int.74c). However, this was refuted by some local state agents, who argued that the mediators did not come to work because they were not motivated. The poor working relationship eventually affected the accountability relations between the MCs and other local state agents, and institutional performance in general. It is important to note that the MCs and other state agents are supposed to work together if they are to establish a successful and effective conflict mitigation process. Ultimately this undermines the efficiency of the MCs. The consequences of this type of relationship are that there is loss of trust among the local state actors involved in the conflict mitigation process. Eventually, the MCs and other local state agents begin undermining each other, and no work is done because team spirit is lacking. Instead a stalemate and inefficiency arise in the conflict mitigation process, and eventually apathy creeps in.

That aside, there are some citizens' who believe that the mediators are transparent in what they do, that the mediation process is done in public, which makes it more transparent, and that it makes the public part of the process of mediation. According to them before the committee makes any decision there is a lot of debate and contestations. The process encompasses both dialogue and arguments, which help the mediators to arrive at the right decisions. Subsequently, this process makes the decision-making process objective. ${ }^{16}$

However, another finding related to the above is that though some of the citizens mention that there was transparency, it was discovered that the majority of the citizens who lost cases did not know how the MCs arrived at the decisions that they made. This may be because they lacked information but it could also qualify as lack of transparency in the whole conflict mitigation process. The problem is accentuated by the fact that the law gives the members of the MCs the prerogative of making the decisions based on laws of the country or local customary practices, provided the decision is not contrary to the written law (Article, 21). ${ }^{17}$ The biggest problem that comes with this approach is that the MCs do not have the tools to guide them on whether to apply the laws of the country or base their decisions on customary practices. This becomes an accountability problem since it indicates that the citizens cannot question the authority of the MCs, due to lack of vital information. In addition it affects the efficiency of these committees. Ultimately this may become a problem as it may affect the legitimacy of the state at local level, as the citizens become dissatisfied with the performance of the MCs.

Finally, the interview material indicates that local-level institutions lack resources. This is something that continuously came up in the meetings. This is a big problem in terms of accountability since continuous improvement depends on the availability of a favorable working environment and infrastructure (cf. Aucoin and Heintzman, 2000:52). This makes being a member of the MCs not attractive, since there are a minimum of benefits. Some members do not see the benefit of being part of the MC. As such, the MCs cannot be answerable to the state if they lack facilities to enable them to work. It is the performance of these committees that generate local state legitimacy. Therefore, the absence of basic infrastructure may become a hindering factor to their performance. It is also a hindrance to the provision of justice. Yet the citizens have no other alternative since a mediation process is mandatory before the citizens appear before any court of law (See Article 26, 27 and 28 Organic law No.02/2010/OL of 09/06/2010).

\footnotetext{
${ }^{16}$ Interview No. 105 with one of the residents of Matyazo cell,

${ }^{17}$ See Article 21, Organic law No. 02/20/2010 OL of 09/06/2010
} 
In the next section, I will present the findings of this study in relation to the legitimacy of the state.

\section{Local state legitimacy}

The above concept was investigated by looking at the views of the citizens and other local actors in relation to local state legitimacy. State legitimacy is about "the very basis on which state and society are linked and by which state authority is justified; It is about a vision of what the authorities and the community is about and are to do" (Bellina, Darbon, et.al, 2009:3). The above definition emphasises that state legitimacy is related to the "satisfaction of people's everyday needs as a source of legitimacy for the state" (Roberts, 2013:6). Therefore, what are the views and experiences of the citizens in relation to local state legitimacy? I base my conclusion on the argument that legitimacy is seen from the perspective of "satisfying the everyday needs of the citizens" (Roberts, 2013:6), where "welfare and entitlement are seen as a 'powerful glue' that binds citizens to their state" (Milliken and Krause 2002, p. 760).

The preamble of the constitution of the Republic of Rwanda begins by, "we, the people of Rwanda (....) resolve to build a state governed by the rule of law (...) based on tolerance and resolution of issues through dialogue" (Constitution of the Republic of Rwanda 2003). It is against this background that the MCs were established, and they are doing what the constitution of Rwanda requests them to do. They were established for purpose of enabling the citizens of Rwanda to have easy access to justice. However, one may not conclusively say to what extent these committees have contributed to the legitimacy of the state at local-level because there are divergent views. What this paper has tried to do is to provide the views and experiences of the citizens and other local actors in relation to local state legitimacy from the perspective of local conflict mitigation. Firstly, there are citizens-particularly the poor-who say that these committees have assisted the local leaders to solve their local disputes. This suggests that the disadvantaged citizens believe that they have benefited from the existence of these committees. Secondly, a large percentage of the citizens were avoiding the courts of law because they did not have the money to pay in the courts of law, but through the MCs they can now access justice. Many of the poor citizens did not even know where these courts of law were located. Others travelled very long distances to reach the courts. Access to justice was extremely difficult since the cost of litigation was extremely high. The courts demanded money that these citizens did not have. The MCs on the other hand handle the disputes of the citizens use local knowledge surrounding these disputes, ${ }^{18}$ which becomes cheaper for the citizens.

However, there were some disputes that were not controversial, like failing to repay debts from a savings group, and failing to honor an agreement when there were documents which showed that one person owed another person's money. In such disputes the MCs imposed sanctions, and the accused citizens would pay. The most interesting part of this type of disputes was that these disputes were of economic nature and others were social conflicts. For example, there were many disputes to do with citizens borrowing money from the cooperatives and the citizens failing to pay in time. The MCs would get involved and they had to ensure that the citizens pay those debts. This could eventually improve the economic situation of the citizens. Above all it is one of the responsibilities of the state to cater and improve the economic needs of the citizens.

${ }^{18}$ See Int. No.75 Nyarubuye cell 


\section{Conclusion}

Generally, the MCs contribution to the state building process is still modest. As earlier mentioned, the lack of resources and infrastructure to enable the MCs do quality work remains the biggest hindering factor in the MCs functioning, which leads the MC members to lose interest in their job, leading in turn to low motivation. This is a big hindrance to their performance and the efficiency of the MCs. Ultimately; this has affected their work tremendously. This indicates that the state-building process based on this strategy may not be sustainable, which resonates with the argument of Putzel that, "participation that requires ordinary people to give their time and limited resources is problematic, as it is hard to sustain" (Putzel, 2003 cited in Golooba 2004:290). Hence, this paper concludes that in the absence of sufficient resources and infrastructure the contribution of these committees to the local state-building process remain modest. However, it is important to observe that the majority of the citizens still have trust in the MCs and appreciate what the MCs are doing, especially the majority of the poor citizens. The trust generated by the MCs can be an indicator that local-level state institutions can provide better management of conflicts since they have the capacity to use local knowledge and context (e.g Schelenberger, 2008:67). As mentioned above the elders and other citizens who are conversant with the local history provide necessary local knowledge. But essentially, this depends on the capacity of the actors and more so the local leaders involved in the process, and the relationship between the state and the local state institutions.

\section{References}

Agrawal, A. and Ribot (1999) “Accountability in Decentralisation.”Journal of Developing Areas, 33:473-502.

Aucoin, P. Heintzman, R. (2000) "The Dialectics of Accountability for Performance in Public Management Reform." in International Review of Administrative Sciences, 66 (1): 4555.

Autesserre, Séverine (2010) The trouble with the Congo: local violence and the failure of international peacebuilding. Cambridge. New York: Cambridge University Press.

Balayet Hossain, (2012) Dispensing Justice Locally: A study of Two Village Courts in Bangladesh. Masters Thesis, North South University Bangladesh.

Bellina, S.; Darbon Dominique; Eriksen, Stein and Sending, Ole Jacob (2009) "The legitimacy of thestate in fragile situations," Report prepared for the OECD DAC International Network on Conflict and Fragility.

Benequista, Nicholas (2009) Backed by Popular Demand: Citizen Actions for Accountability,Brighton:The citizenship DRC Case study Series.

Blair, Harry (2000) "Participation and Accountability at the Periphery: Democratic Local Governance in Six Countries." in World Development, Vol.28, (No.1) 21-39.

Brinkerhoff, D.W. (2001) "Taking Acount of Accountability: A conceptual Overview and StrategicOptions." U.S. Agency for International Development Centre for Democracy and Governance Implementation Policy Change Project, Phase 2 Washington, DC.

Brinkerhoff, D.W. (2011) "State Fragility and Governance: Conflict Mitigation and SubnationalPerspectives." Development Policy Review 29 (2): 131-153. D.;

Chandler, D., Chesterman, S, and Laakso, Liisa (2007) “Editors' Introduction.” Journal of Intervention and State-building, 1:1, 1-2.

Commission on Human Security (2003) Human Security Now. New York: Commission on Human Security.

Crook and Manor (1998) Democracy and Decentralisation in South Asia and West Africa:Participation, Accountability and Performance. Cambridge: Cambridge University Press. 
Curley Alexander Seth (2011) From Village to State: An Ethnography of Local Governmentin Uganda. $\mathrm{PhD}$ dissertation, Yale University

Devas, Nick and Ursula Grant (2003) "Local Government Decision-Making-Citizen participation andLocal Accountability: Some Evidence from Kenya and Uganda." Public Administration and Development, 23 (4): 307-316.

Dewey, Johnn (1954) The Public and its problems. Ohio: Ohio University Press

Doughty, Kristin (2011) Contesting Community: Legalised Reconciliation Efforts in the Aftermath of Genocide in Rwanda. PhD Dissertation University of Pennsylvania, USA.

Eyben, R. and Ladbury, S. (2006) "Building Effective States: Taking a Citizens' Perspective."Development Research Centre, Citizenship, Participation and Acountability. Brighton: Institute of Development Studies.

Fritz, V. and Menocal, Rocha (2007) "Understanding state-Building from a Political EconomyPerspective: An analytical and Conceptual Paper on Processes, Embedded Tensions and Lessons for International Engagement." Report prepared for DFID's Effective and Fragile States Teams. Overseas Development Institute, London.

Fukuyama, Francis (2004) State building: Governance and World Order in the Twenty- First Century.London: Profile books limited.

Golooba-Mutebi, Frederick (2004) "Reassessing Popular Participation in Uganda." PublicAdministration and Development, Vol.24:289-304.

Haider, (2010) "Topic Guide Supplement on State-Building and Peace-Building in Situations of Conflict and Fragility." Governance and Social Development Resource Centre, International Development Department, Birmingham.

Hayward, F.M. (1976) "A reassessment of conventional wisdom about the informed public: national political information in Ghana." American Political Science Review 70(2): 433-451.

Herbst, Jeffrey (2000) States and Power in Africa: Comparative Lessons in Authority and Control.Princeton: University Press.

Hess and Elinor Ostrom (2007) Understanding Knowledge as Commons: From theory to Practice.Massachussets Institute of Technology, MIT

Hyden, G. (1980) Beyond Ujama. London: Heineman Publishers

Justino, Patricia and Verwimp Philip (2008) Poverty Dynamics, Violent Conflict and Convergence inRwanda: A micro-level analysis of violent conflict. Institute of development studies at the University of Sussex, Brighton.

Karugarama, T. (2010) "Forward" in Republic of Rwanda Inyigisho Zigenewe Abunzi, Kigali Ministryof Justice.

Kauzya, John Mary (2005) "Decentralisation: Prospects for Peace,Democracy and Development."DPADM Discussion paper, September 2005. Division for Public Administration and Development Management, United Nations Department of Economics and Social Affairs.

Kauzya, J. M, (2007) "Political Decentralisation in Africa: Experiences of Uganda, Rwanda, and South Africa," in Cheema and Rondinelli (eds.) (2007) Decentralizing Governance: Emerging Concepts and Practices. Washington, D.C: Brookings Institute Press.

Khadiagala. G, and Lyons. T. (2006) "The Challenges of leadership in Post-Conflict Transitions:Lessons from Africa." Conflict Trends. .

Khadiagala G.M.(2007) Meddlers or Mediators? African Interveners in civil conflicts in Eastern Africa. Martinus Nijhoff Publishers. Leiden, Netherlands. 
Kim.S (2012) Democracy in Action:Decentralisation in Post-Conflict Cambodia. School of Global Studies, Gothenburg, University of Gothenburg. PhD dissertation in Peace and Development Research.

Lambright, Gina M,S (2011) Decentralisation in Uganda: Explaining Successes and Failures in Local Governance, london:First Forum Press, Lynne Reinner Publishers, Inc

Lubanga.F.X.K (1996) “The process of Decentralisation” in Villadsen and Lubanga (eds.) 1996 Democratic Decentralisation in Uganda: A new Approach to local Governance.Kampala, Uganda: Fountain Publishers.

Manor, J. (2004) Democratisation with inclusion: Political Reforms and People's Empowerment at theGrassroots." Journal of Human Development 5.1:5:30

Menkhaus, K. (2006) "Governance without Government in Somalia.” International Security 31(3):74-106.

Milliken, J. and Krause, K.,(2002) "State Failure, State Collapse and State Reconstruction: Concepts, Lessons and Strategies," Development and Change, Vol.33, No: 5.

Ministry of Local Government, G.G. Community Development, and Social Affairs: Rwanda Decentralisation Implementation Program 2008-2012 (2008b), Republic of Rwanda, Kigali.

Nordstrom, C. (1997) A different Kind of War Story. Philadelphia: University of Pennyslvania Press.

Organic Law N.31/2006 of 14/08/2006 Organisation, Jurisdiction, Competence and Functioning ofthe Mediation Committee, Government of Rwanda.

Organic Law N.22/99 of 12/11/1999 Completing the First Civil Code Book and Instituting the Fifth Section Relating to Marriage, Patrimony, and Succession. Official Gazette of the Republic of Rwanda.

Paffenholz, T. (2014) “International peacebuilding goes local: analysing Lederach's Conflict transformation theory and its ambivalent encounter with 20 years of practice." Peacebuilding, 2:1, 11-27.

Papagianni, Katia (2008) "Participation and State Legitimation" in Charles T. Call with VanessaWyeth (eds.) (2008)Building States to build Peace. London: Lynne Reinner Publishers, Inc.

Paris, Roland (2004) At War's End: Building Peace After Civil Conflict. Cambridge: CambridgeUniversity Press.

Paris and Sisk (2009) "Introduction: Understanding the contradictions of postwar state building" in Paris and Sisk,(eds.) 2009. The Dilemmas of Statebuilding: Confronting the contradictions of Post War peace operations. London, Routledge Taylor and Francis Group.

Poteete, Amy and Ribot, Jesse (2011) "Repertoires of Domination: Decentralisation as Process in Botswana and Senegal." World Development, Vol.39, No.3:439-449.

Putzel, J. (2003) The politics of participation. Civil Society, the State and development assisatnce.Unpublished, Development Research Centre DESTIN, London School of Economics and Political Science

Ministry of Justice (2010) Inyigisho Zigenewe Abunzi. Republic of Rwanda, Kigali.

Ribot, Jesse (2002) African Decentralisation: Local Actors, Powers, and Accountability. Geneva,Switzerland: UN Research Institute for Social Development.

Richmond. Oliver (2013) "Failed Statebuilding versus Peace formation." Cooperation and Conflict 48(3) 378-400.

Roberts, David (2013) "Everyday Legitimacy and Postconflic States: Introduction," in Journal of Intervention and State-building 7(:1): 1-10. 
Sellers, M. Jefferey, (2011) “State-Society Relations” in Mark Bevir (eds.) (2011) The Sage handbookof Governance. London: SAGE Publications limited.

Thies G Cameron (2007) "The Political Economy of State Building in Sub-Saharan Africa." The Journal of Politics, Vol.69, No.3 (August).

Tilburg, V. Peter (2008) "Decentralisation as a Stabilising Factor in Rwanda" in Crawford and Hartmann (eds.) (2008) Decentralisation in Africa: A Pathway out of Poverty and Conflict. Amsterdam, Amserdam University Press.

Tilly, (1985) "War Making and State Making as Organised Crime" in Evans, Rueschemeyer and Skocpol (eds.) (1985) Bringing the State Back in. Cambridge: Cambridge University Press.

Tilly, Charles (1992) Coercion, Capital, and European States, AD 990-1992 Blackwell Publishing, Malden.

Tocqueville, Alexis de (1969) Democracy in America. Garden City: Anchor Press. Guide USAID/DCHA/CMM). NewYork,USAID.

Walter, B. F. (2004) "Does Conflict Beget Conflict? Explaining Recurring Civil War." Journal ofPeace Research 41(3): 371-388. 